\title{
Meningitis in a Pregnant Woman Caused by Streptococcus dysgalactiae subspecies equisimilis
}

\author{
ROBERT WALTEREIT ${ }^{1}$, ULRICH HERRLINGER ${ }^{1}$, MAIK STARK ${ }^{2}$ \\ and STEFAN BORGMANN ${ }^{2 *}$ \\ ${ }^{1}$ Dept. of General Neurology, Hertie Insitute for Clinical Brain Research, \\ University of Tübingen, Tübingen, Germany \\ ${ }^{2}$ Institute of Medical Microbiology and Hygiene, University of Tübingen, Tübingen, Germany
}

Received 5 October 2012, accepted 24 December 2012

\begin{abstract}
Infection of the central nervous system by streptococci is known to result in severe bacterial meningitis, however some strains have low pathogenic potential and affect the brain only in immunocompromised patients. Here we report the first case of an otherwise healthy non immunocompromised young adult woman who developed meningitis caused by Streptococcus dysgalactiae subspecies equisimilis. The patient was in the $17^{\text {th }}$ week of her $3^{\text {rd }}$ pregnancy. The course of the disease was quickly remittent under antibiotic treatment.
\end{abstract}

Ke y words: Meningitis, Streptococcus dysgalactiae, Coxsackie virus, pregnancy

Whereas species of Streptococcus genus, notably S. pneumoniae, are common causes of severe bacterial meningitis (Meli et al., 2002), meningitis due to $S$. $d y s-$ galactiae has been reported in only 4 cases, all of them in either infants or elderly individuals and with mild clinical course (Luyx et al., 2001, Berenguer et al., 1992, Mollison et al., 1990, Quinn et al., 1978). It is believed that streptococcal meningitis is acquired via transient colonization of the nasopharynx, followed by bacteraemia and invasion of the central nervous system (CNS). To enter the brain via this route, the bacteria require a set of virulence factors that seem to be present in S. pneumoniae strain but not in S. dysgalactiae. In the literature, there was so far no case reported of meningitis in an otherwise healthy adult caused by $S$. dysgalactiae. Here we report the first case of an otherwise healthy non immunocompromised young adult woman who developed meningitis caused by Streptococcus $d y s-$ galactiae subspecies equisimilis.

In the present case, a 38 year old otherwise healthy caucasian woman was admitted to the hospital with acute fatigue, severe headache and temperature of $39.5^{\circ} \mathrm{C}$. She was in the $17^{\text {th }}$ gestational week of her $3^{\text {rd }}$ pregnancy. Because she was working as a staff nurse for children and as a childminder, she had contact to several preschool children including her own, who suf- fered 10 days before admission from an acute febrile pharyngitis, which was self-limiting after 1-2 days. On clinical examination, she presented a mild meningeal irritation, with cephalgia but without any other neurological deficit. Examination of the pharynx was unremarkable. Serum CRP was mildly elevated to $1.7 \mathrm{mmol} / \mathrm{l}$; all other standard laboratory findings were within normal range, including leukocyte count. A lumbar puncture was performed and revealed a pleocytosis

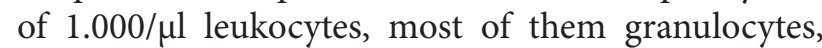
slightly increased albumin concentration $(371 \mathrm{mg} / \mathrm{l})$ and an increased lactate concentration $(2.8 \mathrm{mmol} / \mathrm{l})$. However, culture of CSF revealed no bacterial growth (Table I). Therefore, broad-spectrum amplification of $16 \mathrm{~S}$ rRNA gene was performed in accordance to Goldenberger et al. (1997). Antibiotic treatment was initiated immediately with $2 \mathrm{~g}$ ceftriaxone and $12 \mathrm{~g}$ ampicillin intravenously. Because of pregnancy, the regimen did not include adjuvant dexamethasone treatment. On day 2, cephalgia had improved and temperature declined to $38^{\circ} \mathrm{C}$, and on day 3 , she was asymptomatic. A second lumbar puncture on day 5 showed $25 / \mu 1$ leukocytes, most of them lymphocytes, and no further abnormalities.

On day 6, sequencing of the PCR product from the first lumbar puncture revealed infection caused by

* Corresponding author: S. Borgmann, Klinikum Ingolstadt Dept. of Clinical Infectiology and Infection Control, Krumenauerstr. 25, D-85049 Ingolstadt; phone: 0049841880 2020; fax: 0049841880 2849; e-mail: stefan.borgmann@klinikum-ingolstadt.de; synlab@gmx.de 
Table I

Microbiological findings in CSF from day 1

\begin{tabular}{|l|l|}
\hline Gram and methylene blue stainings & negative \\
\hline Aerobic culture on blood agar & negative \\
\hline Anaerobic culture on brain heart agar & negative \\
\hline PCR of eubacterial DNA & positive \\
\hline PCR of eubacterial DNA (Day 5) & negative \\
\hline Sequence analysis of PCR product & $\begin{array}{l}498 \text { of } 499 \text { base pairs homologous to 16S r-RNA gene sequenc } \\
\text { of the beta-haemolytic bacterium Streptococcus dysgalactiae } \\
\text { subspecies equisimilis }\end{array}$ \\
\hline PCR of enterovirus DNA & negative \\
\hline PCR of Coxsackie virus RNA & negative \\
\hline
\end{tabular}

Streptococcus dysgalactiae subspecies equisimilis. Ampicillin treatment was stopped and ceftriaxone continued until day 14 .

This is the first case, to our knowledge, of meningitis in an otherwise healthy adult associated with evidence of Streptococcus dysgalactiae subspecies equisimilis in cerebrospinal fluid (CSF) (Table I). Although invasive infection (including shock, renal and liver involvement, soft-tissue necrosis, but not meningitis) caused by Japanese strains of $S$. dysgalactiae have been reported, $S$. $d y s$ galactiae usually provides a low pathogenic potential (Ikebe et al., 2004).

In our patient, there were no signs of immune compromission or other overt reasons that may promote invasion of the nervous system. In humans, S. dysgalactiae sometimes is the aetiological agent of pharyngitis especially in children. In humans S. dysgalactiae does not belong to the physiologic flora and infections are caused by person-to-person transmission (Sunaoshi et al., 2010). Therefore, it is possible that the children in our patient's environment, suffering from phar-

Table II

Microbiological findings in serum from day 5

\begin{tabular}{|l|l|}
\hline HSV IgM ELISA & negative \\
\hline CMV IgM ELISA & negative \\
\hline EBV VCA IgM ELISA & negative \\
\hline FSME IgM ELISA & negative \\
\hline Rubella IgM CLIA & negative \\
\hline Coxsackie A9, B1-B6 CBR (Day 2) & $1: 10$ \\
\hline Coxsackie A9, B1-B6 CBR (Day 4) & $1: 40$ \\
\hline Q-Fever CBR & negative \\
\hline Mumps IgM CLIA & negative \\
\hline Measles IgM ELISA & negative \\
\hline Poliovirus CBR & negative \\
\hline VZV IgM ELISA & negative \\
\hline Influenza A CBR & negative \\
\hline Influenza B CBR & negative \\
\hline Mycoplasma pneumoniae CBR & negative \\
\hline
\end{tabular}

yngitis, were infected with $S$. dysgalactiae and transmitted the bacteria to her. However, we still have to ask what could have allowed the exacerbation from benign pharyngitis to meningitis in this case. There are - as far as we can realize - two characteristics in which our patient differed from completely normal individuals. The first point is that our patient was in the $17^{\text {th }}$ week of her $3^{\text {rd }}$ pregnancy. Pregnancy is a complex phenomenon associated with metabolic and immunological changes in the child-bearing mother. Nevertheless, the literature does not provide evidence that during pregnancy bacterial invasion of the maternal CNS is more common. The second point is that we observed concomitant infection with Coxsackie virus in our patient. The increase of Coxsackie virus neutralization reaction (Table II) indicates an acute infection. Although Coxsackie virus itself can cause meningitis, we could not detect Coxsackie virus RNA by PCR (Kämmerer et al., 1994) in CSF (Table I). Therefore, it could be speculated whether the concomitant Coxsackie virus infection, demonstrating limited course, was an additional factor that triggered meningitis formation by $S$. dysgalactiae in this case.

However, it is of note that this $S$. dysgalactiae associated meningitis was very mild, was beyond headache and fever without other clinical signs of meningitis, was quickly remittent under antibiotic regimen, and only diagnosed by lumbar puncture. Further, admission to the hospital occurred only because our patient was worried on account of her pregnancy. As the bacteria were not found in our case by culturing, it may be possible that they were already damaged by sufficient immune response, suggesting self limiting infection; and it can be speculated whether this clinical presentation would have been self limiting without any medical treatment. Often, CSF from patients showing mild symptoms are not analysed by PCR, and based on the lack of microbiological findings, the cause of the infection remains unknown. Thus, meningitis in healthy adults by $S$. dysgalactiae could be more common than previously reported. 
Acknowlegdements

The authors thank Dr. Stefan Jürgens for performing Coxsackie virus analysis.

\section{Literature}

Berenguer J., Sampedro I., Cercenado E., Baraia J., RodriguezCreixems M. and Bouza E. 1992. Group-C beta-hemolytic streptococcal bacteremia. Diagn. Microbiol. Infect. Dis. 15: 151-155.

Goldenberger D., Kunzli A., Vogt P., Zbinden R. and Altwegg M. 1997. Molecular diagnosis of bacterial endocarditis by broad-range PCR amplification and direct sequencing. J. Clin. Microbiol. 35: 2733-2739.

Ikebe T., Murayama S., Saitoh K., Yamai S., Suzuki R., Isobe J., Tanaka D., Katsukawa C., Tamaru A., Katayama A. and others. 2004. Surveillance of severe invasive group-G streptococcal infections and molecular typing of the isolates in Japan. Epidemiol. Infect. 132: $145-149$.
Kämmerer U., Kunkel B. and Korn K. 1994. Nested PCR for specific detection and rapid identification of human picornaviruses. J. Clin. Microbiol. 32: 285-291.

Luyx C., Vanpee D., Glupczynski Y., Swine C. and Gillet J.B. 2001. Delayed diagnosis of meningitis caused by beta-haemolytic group G. Streptococcus in an older woman. J. Emerg. Med. 21:393-396. Meli D.N., Christen S., Leib S.L. and Tauber M.G. 2002. Current concepts in the pathogenesis of meningitis caused by Streptococcus pneumoniae. Curr. Opin. Infect. Dis. 15: 253-257.

Mollison L.C. and Donaldson E. 1990. Group C streptococcal meningitis. Med. J. Aust. 152: 319-320.

Quinn R.J., Hallett A.F., Appelbaum P.C. and Cooper R.C. 1978. Meningitis caused by Streptococcus dysgalactiae in a preterm infant. Am. J. Clin. Pathol. 70: 948-950.

Sunaoshi K., Murayama S.Y., Adachi K., Yagoshi M., Okuzumi K., Chiba N., Morozumi M. and Ubukata K. 2010. Molecular emm genotyping and antibiotic susceptibility of Streptococcus dysgalactiae subsp. equisimilis isolated from invasive and non-invasive infections. J. Med. Microbiol. 59: 82-88. 
